A sua preocupação metodológica pode ser resumida no seguinte trocho: "alguns documentos e obras, dos mais importantes para a história de Paris, não apresentam para nós senão um interêsse mínimo. Longe de quirer efetuar um histórico das vias de Paris, sòmente retivemos os dados que se relacionam com a origem da formação de uma via de passagem, às etapas de sua urbanização, para explicar ou servir de material à explicação de sua estrutura atual. Isto, no final das contas, permaneceu como nossa meta essencial. Da mesma maneira, climinamos tudo o que se relaciona com a formação de vias atualmente desaparecidas, a não ser que vcnham explicar a formação das vias atuais".

$\mathrm{Na}$ primeira parte encontramos os fundamentos da rêde topográf:ca de Paris. Inicialmente vemos a evolução desde as origens até o final do século XII, distinguindo os caminhos naturais da época gaulesa, os traçados romanos e as vias formadas na alta Idade Média; posturiormente o autor expõe o desenvolvimento da rêde das vias no século XIII,mostrando o traçado e as funções atuais dos caminhos ligados ao circu.to de Filipe-Augusto, e as repercussões oriundas com a instabilidade política e o "renascimento" de Paris no decorrer dos séculos XIV ao XVI; aborda dipois os acontecimentos relacionados com a obra jurídica e a utilização dos bens nacionais, ocorridos de 1790 a 1830 e, por último, as características da formação das ruas e de suas funções.

$\mathrm{Na}$ leitura desta obra de Rouleau realça a acuidade de uma pesquisa minuciosa, que se reflıte numa descrição detalhada e muito bem documentada. As ilustrações somam quinze cartas e vinte e três figuras, facilitando o acompanhamento do texto e das transformações havidas, além de uma carta de referência na escala de 1:25.000, expondo as vias parisienses principais e seus nomes. A propósito desta carta de referência,assim como em outras encontradas no texto, cumpre lembrar uma questão de terminologia. : A carta inserida denomina-se "plano topográfico de Paris", apresintando a distribuição das ruas parisienses. Ora, o têrmo topográfico, nos estudos geográficos, aplica-se normalmente às cartas representativas das formas de rílêvo de uma área, e não ao traçado urbano. Mas, como um grão de areia não caractcriza a praia, e a omissão acima pode ser colocada nesta proporção, a obra de Rouleau é fundamental para quem se interessa em realmente conhecer a geografia e a evolução histórica da capital francesa.

\title{
ANTONIO CHRISTOFOLETTI
}

GOODSPEED (D. J.). - Ludendorff. Rio de Janeiro. 1968. Tradução de Eloywaldo Chagas de Oliveira. Biblioteca do Exército em co-edição com a Editôra Saga. 345 páginas.

Justificando a publicação desta obra e eximindo-se de qualquer crítica que porventura the possa ser feita, apressa-se a editôra em explicar que ao lançar a biografia de Ludendorff, "Ionge de nós a idéia de reviver o prussianismo ou de pugnar pela apologia da guerra, pois como militares que somos, conhecemos melhor que ninguém quais os horrores que dela decorrem. No desijo de fornecer aos 
nossos leitores os mais variados assuntos, selecionamos esta obra tendo em mente não só os aspectos históricos como também a figura de um homem discutido, que, durante a primeira guerra mundial, enfeixou em suas mãos, na Alemanha, um poder excepcional". E adiante: "Talvez o maior estigma, aquêle que acompanhará Ludendorff para sempre, é o de que êle foi um dos responsáveis pela ascensão de Hitler". O assunto é por demais complexo e muito há ainda a escrever-se sôbre êle. Em que pese tôdas as precauções dos editôres, é inegável que se trata de valiosa contribuição para a história militar das duas grandes guerras mundiais.

\section{ODILON NOGUEIRA DE MATOS}

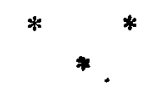

BERNARD (Henri), CHEVALLAZ (André), GHEYSENS (Roger) e DE LAUNAY (Jacques). - Os arquivos da segunda guerra mundial. [Les dossiers de la seconde guerre mondiale]. Tradução de Vasco Pulido Valente. São Paulo, Difusão Européia do Livro. 1969. 262 páginas. (Enciclopédia de Bolso Difel).

O presente volume, editado pela Difusão Européia do Livro em convênio com a Livraria Bertrand, de Lisboa, foi publicado sob os auspicios da Comissão Internacional do Ensino da História que, para tal fim, convidou quatro historiadores, todos especialistas nos seus respectivos domínios, capazes todos de uma contribuição positiva para traçar as linhas mestras dessa "história definitiva", que tão cedo não poderá ser escrita, da segunda guerra mundial. Henri Bernard ("As batalhas decisivas") mostra em que datas precisas e em que condições os movimentos ofensivos das fôrças do Eixo foram detidos. Dá ênfase à evolução do armamento e das técnicas aeronavais, evolução que veio permitir operações de grande envergadura de um estilo completamente nôvo. Géorges André Chevallaz ("As grandes conferências diplomáticas") examina o sentido dos acontecimentos diplomáticos, as causas distantes da guerra e identifica os grandes fatos dilomáticos que permitiram o desenvolvimento da guerra na Europa (Pacto germano-soviético) e no sudeste asiático (Pacto nipo-soviético). A análise que faz das grandes conferências interaliadas permite descobrir quais foram as grandes decisões que refizeram o mapa do mundo, assim como as intençôes que as motivaram. Roger Gheysens ("O verdadeiro papel da espionagem"), pondo de parte as histórias rocambolescas, mais ou menos imaginárias ou romanceadas, tenta apurar qual foi o verdadeiro papel da espionagem no decurso da guerra. Faz o inventário dos fatos de veracidade confirmada e explica como é que a luta dos serviços de informação se desenvolveu através da utilização de meios técnicos aperfeiçoados de codificação e decifração. E demonstra também porque é que o problema crucial da crítica das informações não recebeu nenhuma solução satisfatória. Finalmente, Jacques de Launay ("A guerra psicológica") tenta precisar as razões que levaram os novos meios de comunicação (rádio, imprensa) a desempenhar um papel inteiramente nôvo na guerra, fazendo as populações civis participarem dela, como nunca havia ocorrido. O seu ensaio sôbre a guerra psicológica, respectivas vitórias e derrotas, 